Wilfrid Laurier University

Scholars Commons @ Laurier

Fall 2009

\title{
The Maritorious Melodrama: Film Noir with a Female Detective
}

Philippa Gates

Wilfrid Laurier University, pgates@wlu.ca

Follow this and additional works at: https://scholars.wlu.ca/engl_faculty

Part of the English Language and Literature Commons, Film and Media Studies Commons, and the Gender and Sexuality Commons

\section{Recommended Citation}

Gates, P. (2009). "The Maritorious Melodrama: Film Noir with a Female Detective." Journal of Film and Video 61.3 (Fall 2009): 24-39.

This Article is brought to you for free and open access by the English and Film Studies at Scholars Commons @ Laurier. It has been accepted for inclusion in English and Film Studies Faculty Publications by an authorized administrator of Scholars Commons @ Laurier. For more information, please contact scholarscommons@wlu.ca. 


\section{The Maritorious Melodrama: Film Noir with a Female Detective Philippa Gates}

Feminist critics tend to disagree whether the parachuting of women into traditionally male roles—-for example, that of detective—results in a feminist representation. ${ }^{1}$ The female detective of the 1930s, however, can be seen to offer a decidedly positive feminist hero in that she defies the stereotype of the "masculine" (i.e. unnatural) woman-especially when one considers the time in which she appeared and representations of female detectives in contemporary film. ${ }^{2}$ Despite popular conceptions of classical film, Hollywood did offer progressive representations of working women, ironically in the decade characterized by economic and social upheaval during the Depression. The prolific female detective of 1930s B-films and series is an independent woman who puts her career ahead of the traditional female pursuits of marriage and a family, and who chases a mystery as actively and with greater success than the men who populate the police department or a rival newspaper's staff. However, during World War II and especially its aftermath, the representation of the female detective began to change, and the independent woman came to be depicted as all but the criminal herself.

In this paper, I explore the representation of the female detective in film noir of the 1940s and the shift from the celebration of the independent and career-oriented woman to her demonization. Critics of film noir have discussed at length the figure of the femme fatale as dangerous femininity but noir's female investigative protagonists have been ignored. ${ }^{3}$ In this paper, I will discuss how the sex of the investigating protagonist complicates the traditionally male noir detective narrative. The result is a hybridization of generic conventions: the narrative is driven forward as much by the female protagonist's personal desires as with many types of melodrama (specifically the woman's film) as by her investigation as with a detective film; ${ }^{4}$ 
however, at the same time, the heroine's independence as a detective poses an undesirable challenge to the masculinity of her husband (or husband-to-be) as with film noir. Just as the maternal melodrama demanded a woman make personal sacrifices to facilitate her daughter's success in the world, so too do these noir films demand the sacrifice on the part of the female protagonist to see the man she loves returned to his "proper" place as head of the household. Thus, I term these films "maritorious melodramas" as opposed to maternal as they see the female protagonist "excessively devoted" to her husband. ${ }^{5}$ In the noir films Phantom Lady (Siodmak 1944), Black Angel (Neill 1946), and Woman on the Run (Foster 1950), the heroine is offered simultaneously as a progressive image of femininity—because she occupies the center of, and drives forward, the investigative narrative — and as a contained one-because ultimately she is proven incompetent as a detective and is returned to the prescribed social role of devoted and sacrificing wife.

\section{From Career Woman to Wives}

The female detective was an ideal heroine for the Production Code as one whose sexuality was literally kept under the wraps of her tailored suit while the focus of the narrative was on her investigation of a crime. ${ }^{6}$ While her popularity and increased presence on screen by the mid1930s might be related to the stricter enforcement of the Code by 1934, the female detective was a notable figure in the early 1930s as well and was most likely the result of the industry-wide shift to sound at the dawn of the decade. Certainly the fast-talking woman and her penchant to engage in witty banter with male rivals seemed well suited to the "talkies" and saw the detective film in keeping with the themes of the screwball comedy_including the inversion of sex roles. The female detective was a women operating in the male-dominated world of criminal investigation and, as a woman with authority and power over men, could be regarded as a 
potential disruption to dominant masculinity-just like the criminal. Kathleen Gregory Klein suggests that the female detective must be put in her "proper" (i.e. secondary) place: "Like the criminal, she is a member of society who does not conform to the status quo. Her presence pushes off-center the whole male/female, public/private, intellect/emotion [...] dichotomy” (4).

While this may be true in the 1940s, the 1930s offered a relatively unproblematic celebration of a "masculinized" woman. The women detective of the 1930s was most often a girl reporter, the most famous of which was Torchy Blane. In Smart Blonde (McDonald 1937), Torchy (Glenda Farrell) chases a train on foot: Torchy leaps on board the deck of the caboose as a male action hero would and then simply straightens her coat in order to enter the train car and pass as a "respectable lady." This strong female role on screen was facilitated by the socioeconomic moment—as the reality of the Depression saw more women seeking employment out of necessity_and also the social climate—-with a seeming social desire for gender equality. Klein argues that the growing availability of birth control in the 1920s, and more importantly its social acceptance with popular marriage manuals encouraging its use, helped to redefine marriage (at least for middle-class women) emphasizing the wife's “companionate” rather than maternal role (97). This shift to a "companionate” role was reflected in 1930s films with a new gender equality defining heterosexual relationships. As Philip Hanson notes,

approved heterosexual male and female romantic equality becomes the desired ideal. Especially in an economic period when positing an alternative ideal in place of the perceived failed dynamics of the Hoover era was bankable with mass audiences, a new romantic equilibrium materialized on the screen. (132)

This equilibrium resulted in the depiction of the female detective being more interested in catching her man—as in the criminal-than catching a man-as in a husband. The 1930s detective film always concluded with the solution of the mystery but often also a marriage 
proposal for the heroine from her investigative rival. While many female detectives did accept the proposal, just as many others did not—especially those who starred in film series. After all, getting married would undoubtedly mean giving up her career (and the end of the series) and the female detective was not always ready to assume her prescribed social role. ${ }^{7}$ As Florence Dempsey (also played by Glenda Farrell) in Mystery of the Wax Museum (Curtiz 1933) tells her more feminine friend Charlotte (Fay Wray), "You raise the kids; I’ll raise the roof![...] I would rather die with an athletic heart from shaking cocktails and bankers than expire in a pan of dirty dishwater!”

Carla Kungl notes that, in the heyday of detective fiction during the 1920s and 30s, not to be married signaled the failure of the female detective as a woman (88). Therefore, what is interesting about the Hollywood's female detective is not that she could be a detective and attract a man, but that she attracted her man because of her masculinity—her outspoken nature, her independence, and her careerist ambition, drive, and success. In other words, she was presented as a positive feminist role model: a woman who could be masculine and valued, respected, and desired rather than seen as unnatural (i.e. a lesbian). In this way, the female detective of 1930s Hollywood film defies both the assumptions and stereotypes of the detective tradition but also of the representation of women on the screen — that women had to be the epitome of glamour and femininity to be regarded as models of womanhood. While female aggression in the 1920s had been, as Hanson notes, “consistently contained by being enfolded in male authority” (132n39), in the 1930s it was sometimes celebrated but always allowed. The female detective was simultaneously masculine and feminine, successful in a man's world and a woman's, and was not punished for her social transgressions.

America's involvement in World War II sparked, however, not only the repolarization of gender roles but also a desire for introspection. This resulted in both the phasing out of the female 
detective and any comedy from the detective film and the emergence of film noir and its focus on a male protagonist and social critique. The focus of the detective film in the 1930s, in a reflection of British golden age detective fiction, was on the solution to the mystery and the restoration of order to what was regarded as a generally good society; however, film noir, in a reflection of American hardboiled detective fiction, was more concerned with the darker side of human relationships (especially betrayal) and presented a society that was flawed and often corrupt. In Hollywood's darker film noir, the female detective became a rarity and, in the few films in which she appears, she was most often a housewife trying to clear her husband's name. ${ }^{8}$

\section{Noir and Melodrama}

Phantom Lady (1944), Black Angel (1946), and Woman on the Run (1950) have all been identified as film noir by critics, the Internet Movie Database, and/or distribution companies which have released these titles as part of noir DVD collections. I will, therefore, not spend time in this paper establishing how these films can be regarded as noir but begin with that assumption and, instead, explore how they are also melodrama. There is something different about the film noir featuring a female protagonist. As Donald Phelps notes, "the best of the Woolrich adaptations_epitomized by Roy William Neill’s Black Angel_express something virtually alien to noir mood and noir ethos: a lingering, faintly nostalgic sensitivity, a persistent albeit wistful humanism” (64) leading Phelps to define such films as "cinema gris" rather than noir. I would argue that similarly Phantom Lady (another Woolrich adaptation) and Woman on the Run possess a "nostalgic sensitivity" in keeping with the tradition of melodrama. However, it is not just a female protagonist and a sense of nostalgia or humanism that complicate the identification of these films as noir but also their moments of excess in terms of representation. 
Films are identified as belonging to a specific genre based on their emotional effect (i.e. the horror film), content (i.e. the musical), themes (i.e. the social problem film), setting (i.e. the Western), or protagonist (i.e. the gangster film). However, both melodrama and film noir are examples of categories that have been constructed by critics rather than the film industry itself and have resisted a clear delineation as genre. The label film noir was applied retrospectively by French critics to describe a body of Hollywood films that appeared during World War II. At the time of their release, these films were sold by studios as detective films, crime melodramas, or thrillers; indeed, many of the films were adaptations of hardboiled stories by American authors like Dashiell Hammett, Raymond Chandler, or Cornell Woolrich. Critics have disagreed whether or not film noir is a genre, a style, or a movement but tend to agree that, whatever it is, classic film noir saw its heyday during and immediately after World War II. $^{9}$ Film noir arose in a rebellion against the stylization of classical Hollywood film and offered, in contrast, darker narratives, characters, themes, mood, and cinematography. As James Naremore argues, the use of the term film noir was not widespread until the 1970s and was a creation of a belated rereading of classical Hollywood by scholars and critics (14)_as was the case with melodrama. Today, the term melodrama is most often associated with films featuring heightened emotionality and female protagonists, aimed at an assumed female audience. However, as Ben Singer argues, melodrama was initially a term used by the film industry during the silent era to describe films with "action, thrilling sensationalism, and physical violence” (95). Similarly, Steve Neale suggests that in classical Hollywood film, the term was used by studios to describe "war films, adventure films, horror films, and thrillers, genres traditionally thought of as, if anything, 'male”” ("Melo” 69)— rather than the woman's film. The term's association with narratives driven by female desire has been the result of feminist and psychoanalytic critical discourse of the 1980s and 90s that applied 
the term to classical Hollywood films that, at the time of their release, were labeled-and often dismissed as—woman’s films or “weepies.”10

Critics identify visual style as a key component of film noir. Hollywood directors and cinematographers developed a dark and ominous tone by opting for a chiaroscuro visual stylewith contrasting light and dark shadows - versus Hollywood's dominant style of high-key lighting. Echoing German Expressionism of the 1910s and 20s, film noir offered a highly stylized visual design that drew attention to itself and suggested an exteriorization (or expression) of a character's internal state of mind. Neale argues that the elements regarded "as exclusive to noir" and "its principal hallmarks" are "the visual and aural rhetoric-the use of extreme chiaroscuro, discordant sounds and music, and other expressive and 'expressionistic' devices” (Genre 16970); however, I would note that such "visual and aural rhetoric" have also been identified as the hallmarks of melodrama. As Laura Mulvey notes, "the melodrama is characterized by the presence of a protagonist whose symptomatic behavior emerges out of irreconcilable or inexpressible internal contradiction, and this 'unspeakable' affects and overflows on to the mise en scène” (“It” 125). The heightened emotionality of noir, however, does tend to result from violence while melodrama's stems more often from pathos; this is most likely why a murder was added to James M. Cain's novel Mildred Pierce (1941) in its adaptation into a film noir (Curtiz 1945). Melodrama's visual design includes an emphasis on the symbolic nature of everyday objects as defining social and psychic space: clothing, colors, and household objects become invested with meanings beyond their superficial or obvious ones. Critics have argued that the moments of excess in melodrama puncture the surface realism of the text and can allow for a "reading against the grain" that reveals meanings in opposition to the dominant discourses of capitalism (in the case of a Marxist approach) and patriarchy (in the case of a feminist approach). ${ }^{11}$ This reading of the melodramatic text through a psychoanalytic lens treats the text as 
a hysterical body like that of the patient in psychoanalysis: the surface of the text exhibits symptoms (the moments of excess) that are caused by the contradictions present beneath a surface that cannot contain them (i.e. patriarchal capitalism in opposition to an individual's own desires). Both noir and melodrama offer symbolic images that invite a reading beyond their presence merely as objects befitting their settings: the television that represents how the consumerist trappings of a suburban lifestyle have all but embalmed widow Cary Scott (Jane Wyman) in All that Heaven Allows (Sirk 1955) functions similarly to the image of the "Spade and Archer" sign cast in shadow (and in reverse) on the office floor between the two detectives in The Maltese Falcon (Huston 1941) that represents the dissolution of their supposed partnership.

As I have discussed elsewhere, the term melodrama does not have to be restricted to the discussion of classical Hollywood woman's films, but is applicable to male genre films-for example, the cop-action film. ${ }^{12}$ I would argue that so too can the term be more closely associated with the predominantly male genre of film noir whereas other critics have seen it as an either/or debate, for example Stephen Gale and Pam Cook. I argue that melodrama and film noir are not so distinct from one other but operate similarly as modes of representation that utilize their visual and aural expression to invite their symbolic interpretation. Unlike the classic realist text in which the mise en scène-including sets, costumes, music, and lighting —is expected to perform merely as the backdrop to the story and characters, the noir or melodramatic text sees its mise en scène highlighted, offering a second level of representation through which to interpret the themes and characters.

The most obvious difference between melodrama and film noir is the sex of the protagonist and that of the film's intended viewer. While some films identified as noir have a female protagonist at the center of its narrative (for example, Mildred Pierce starring Joan Crawford), the vast majority of noir films have male heroes (or anti-heroes). Similarly, while 
some well-known family melodramas have a male protagonist at their centre (for example, Written on the Wind [Sirk 1956] starring Rock Hudson) the majority of melodramas are regarded as "women's films"-films starring, and aimed at, women. Certainly, the main thrust of film noir seems to be a negotiation of the anxieties of postwar masculinity. Ex-servicemen returning from the war faced unemployment, alienation, degradation, disablement, and broken homes. Many of these problems were regarded as the result of increased female independence and changing gender roles. In reality, many women had left the home to take up employment and pursued sexual gratification in the absence of their husbands; in film noir, these women were branded as evil—competing with men in the workplace for jobs, at home as breadwinners, and in bed by challenging their husband's masculinity. In melodrama, on the other hand, men were often the cause of the female protagonist's problems - from authoritarian patriarchs to lovers who wished to quell her independence and force her to assume her socially prescribed role as wife and mother. Christian Viviani argues that the Americanization of melodrama made it relevant for the social realties of the 1930s and resulted in the subgenre of the "maternal melodrama," in which a mother makes sacrifices for her child in order to right her social wrong (96). In general, melodramas center on female sacrifice; for example Dark Victory (Goulding 1939) which sees Judith Traherne (Bette Davis) punished for her independent nature with a terminal illness but rewarded for her devotion to her doctor with happiness for a brief while as his wife and Now, Voyager (Rapper 1942) which sees Charlotte Vale (Davis again) sacrifice a relationship with a married man in order to see his daughter (unwanted by her own mother) have a happy childhood.

I would like to suggest that Phantom Lady, Black Angel, and Woman on the Run are not just noir but also melodrama — both in the conventional sense and my complication of those definitions as outlined above. The visual style of the three films is consistent with that traditionally defined as noir but all three films have key moments of excess that are more in 
keeping with conventional notions of melodrama, including the drum solo in Phantom Lady, Marty's amnesia in Black Angel, and the rollercoaster ride in Woman on the Run. As Neale explains, most critics argue "that desire in noir tends to be marked as dangerous or destructive, and that it tends to be represented from a male point of view" (Genre160). And it is in this way that the three films I explore are different from traditional noir: female desire is seen as salvation and is represented from a female point of view. Rather than the exposure of the hero's love interest as a femme fatale and his rejection of her as is typical of noir, Phantom Lady and Black Angel begin with a femme fatale's demise and conclude with the creation of a new family order. Noir has also been seen as the site of male crisis ${ }^{13}$ but these films focus instead on a crisis of female identity in terms of what role these heroines will play to save the men they love-from lounge singer to detective, from adulteress to dutiful wife.

Scholars such as Tania Modleski and Diane Waldman suggest that a small group of gothic thrillers centered on a female protagonist, including Rebecca (Hitchcock 1940) and Gaslight (Cukor 1944), can be regarded as film noir; however, Neale argues that the position of these films has "always been ambiguous or marginal, as far as proponents of noir have been concerned" (Genre 163). Catherine Ross Nickerson argues that detective fiction in general grew out of the gothic tradition, including Edgar Allen Poe's seminal tales of ratiocination (xiii); however, there is an even closer connection between the gothic and women's detective fiction arising from the tradition of the "female gothic" established by Ann Radcliffe’s The Mysteries of Udolpho (1794) in which a female protagonist is faced with a secret or mystery. However, the female gothic thrillers of the 1940s tend to feature women in period piece settings and in roles typical of the woman's film not, as the three films I discuss, in contemporary urban settings and in the traditionally male and noir role of detective. ${ }^{14}$ 
Phantom Lady, Black Angel, and Woman on the Run offer an interesting hybridization of what are regarded as traditionally either noir or melodrama conventions: they offer the female protagonist of the melodrama and a narrative driven by her desires but a protagonist who is simultaneously the problematic independent women of the wartime-era film noir. Like the women of the maternal melodrama who had to sacrifice their own desires to see their children thrive, these female protagonists must make sacrifices in order to reinstate their husbands to their patriarchal position — from criminal to head of the household. It is this excessive devotion to their husbands that invites me to term these films "maritorious melodramas.”

\section{The Maritorious Melodrama}

Whereas the 1930s seemed to call for new kinds of gender roles and Hollywood had answered with gender-bending female detectives, the 1940s seemed to desire the return to traditional polarization of masculinity and femininity: in other words, men had to be remasculinized and women refeminized. Phantom Lady, Black Angel, and Woman on the Run all suggest that the marriages that begin the films have failed because an imbalance in gender power occurred: the wives became too tough or independent and the husbands too “soft”- to use Carol Richman's description of her boss in Phantom Lady. In a reflection of this repolarization of gender, the female detective's only outings in film noir are as a wife (or future wife) attempting to clear her husband's name and repair the broken home. Both Black Angel and Phantom Lady are based on novels by Cornell Woolrich and, as Phelps says of Woolrich’s detective heroines, “The women are fired with devotion, defiance, maternal passion" (66). Just as in the maternal melodrama "the mother's fall from grace was symbolized by a tormented odyssey which marked an opposition to the permanence of the bourgeois household” (Viviani 86), so too is that of the heroines of the these three films marked by a tormented odyssey through the public spaces of the city-the 
courthouse, the night club, the seedy hotel, and the street-in order to return permanence to the bourgeois household. All three films are noir detective films with an expressive use of chiaroscuro visual style and an exploration of the seedier side of America's urban life (New York, Los Angeles, and San Francisco, respectively) but each is also a melodrama with a female protagonist at its center, a narrative driven by her goals and desires, and moments of excess that puncture the surface realism of the text.

Phantom Lady finds Scott Henderson (Alan Curtis) in a bar alone: he was making one last attempt to heal the estrangement between himself and his wife with a night out to celebrate their fifth anniversary, but his wife refused to join him. Scott blames his wife for the collapse of their marriage: she was "too spoiled and too beautiful," he explains to the police. Scott is unaware his wife, Marcella, has been, according to his friend Jack Marlow (Franchot Tone), “amusing herself” with him. When Marcella admits to Jack that she has no intention of leaving her husband for him, he strangles her in a fit of rage. As Scott explains to Inspector Burgess (Thomas Gomez), Marcella refused to be "his wife" (i.e. his lover) but also refused him a divorce (giving him the freedom to pursue another), giving him motive and making him the prime suspect in her murder. In a melodramatic manner, Marcella haunts the early part of the film but is never shown in person. While the police question Scott about his wife, her full-length portrait dominates the wall behind them (using the same technique that is identified with Otto Preminger's Laura released later that year). When the paramedics carry her out, the camera pans somewhat awkwardly past Scott, mirroring her body's passage through the room. Scott exclaims in horror, "Look what they're doing! Her hair... along the floor!” but the audience sees nothing but the frozen portrait on the wall behind. Marcella is, ironically, not the "phantom lady" of the film's title; instead she is Anne Terry (Fay Helm), the woman with whom Scott spent his anniversary evening but who cannot be found by the police to corroborate his alibi. 
The film introduces the heroine, Scott’s assistant, Carol Richman (Ella Raines), at work listening to his Dictaphone message until the story in the paper about Marcella's murder catches her eye. Scott calls her "Kansas” after her home state and to highlight that she is a small-town girl now living in the big city. Carol is in love with her boss and, when he is convicted of murder and sentenced to death row, she decides to play detective to clear his name. She pursues people in the case that swore they never saw the phantom lady; as Carol suspects, each has been bribed to remain silent. Her search leads her through the underbelly of the city and, while these shady places are typically noir, they are also presented through melodramatic excess. Carol stalks the bartender at work and then on his way home: as they wait alone on the platform for the train, the bartender advances threateningly towards Carol and his implied desire to push her in front of the train is halted only by the arrival of another passenger. The tension of the scene is released by the loud squeal of the rain's wheels on the track as it rushes past them. This is echoed in the following scene when the bartender accidentally steps out in front of a car to escape her interrogation and the screams of a woman fuse with the screeching of car tires.

Similarly, the film's most notorious scene-the drum solo-is notable because of its excess. In order to get close to drummer Cliff Milburn (Elisha Cook Jr.), Carol presents herself as a cheap “dame” and gives him "the eye.” He takes her to a basement jam session in which he plays the drums and she dances. Her masquerade of available sexuality is successful at least in his eyes and broken only for a moment when she catches the sight of her own image in a mirror while reapplying her lipstick: she shakes her head in disgust at what she sees. Tension in the scene is built through the frenzied music and atypical cinematography-low and canted angles coupled with tight close ups-and then released with the drummer's orgasmic crescendo. Carol agrees to go back to Cliff's place knowing that he expects her to have sex with him. When she plays hard to get and he spies the police file in her purse, he turns violent and — it is suggested- 
will rape her. He says menacingly, “Wait until I get you!” but she escapes. When Jack (the man responsible for the murder and bribery) turns up after her sudden departure, he says to Cliff, "She was magnificent! She loathed you but she went with you. She would have humiliated herself to make you talk." Her willingness to "humiliate herself" in order to save the man she loves, sees Carol rewarded. When Jack warns Carol that she is risking her life pursuing what he calls "a man’s job” (i.e. playing detective), Carol retorts, “Do you think I'd care? Do you think I'd want to live?"

The film ties the loss of love to madness with two possible outcomes: Anne Terry becomes a reclusive hysteric following her fiancé's death and Jack Marlow becomes a "homicidal paranoiac" when Marcella rejects him. The former represents Carol’s possible future if she does not save Scott from death row. Saving him is, in every way, safeguarding her own future as a woman as the film suggests that a woman is nothing unless she marries the man she loves. And it would seem that Carol gets her happy ending. Returning to work, Carol finds a proposal from Scott on the Dictaphone: "You know you're having dinner with me tonight, and tomorrow night, and the next night, and then every night.” It is on this last phrase that the Dictaphone skips and continues to do so, ending the film with the image of an ecstatic Carole, holding the horn and listening to Scott's disembodied voice repeating "every night...every night...every night.”

In Black Angel, Kirk Bennett (John Phillips) is arrested and later convicted of murdering Mavis Marlowe (Constance Dowling), a singer who is blackmailing him over their affair. Unlike Carol who is a career woman, Cathy Bennett (June Vincent) is a meek and dutiful housewife and she stands by her husband even though, as Martin Blair (Dan Duryea) describes it, Kirk "let her down" (i.e. he was unfaithful). As she explains to her husband in prison, "Please, Kirk. You're my husband. I'll always stand by you. You know that.” Initially, she pursues the other most likely 
suspect in the case, Mavis's ex-husband Marty, but, when it appears that he has a solid alibi, she teams up with him to investigate club owner Marko (Peter Lorre). The missing piece of evidence is the heart-shaped ruby brooch that Kirk swears was on Mavis when he first discovered her body and was later stolen; without the brooch, there is no evidence of a killer other than Kirk.

Marty and Cathy team up not just as investigative partners but also business partners and gain access to Marko’s office and his safe (where Cathy assumes the stolen brooch is hidden) by posing as an entertainment duo: he plays piano while she sings. It is never explained why Cathy's husband strayed and who was to blame, but it was clear that they had become estranged. When Marty asks if she plays the piano, she explains that Kirk used to play while she sang- “At least...we did when we were first married.” One suspects that what attracted Kirk to Mavis was a seductive sexuality and strength of character that Cathy seems, at least initially, to lack. Cathy, however, undergoes a gradual transformation from a meek housewife sporting a checked dress and straw boater, to a working woman in a tailored suit, to a glamorous lounge singer in a black, off-the-shoulder gown. Ironically, it is in the male role of detective that Cathy is refeminized visually. Cathy proves that she does possess a masculine strength of character:

Cathy: "I was hoping to get closer to that safe."

Marty: “That's the hard way, isn't it?”

Cathy: "I have to get into it, Marty...no matter how."

The "hard way" is to become Marko’s lover and even though Cathy is prepared to "humiliate" herself to save her husband, she is still horrified at the thought of it - and the cinematography expresses that horror. In the midst of an otherwise unremarkable scene in terms of film style, there is a melodramatic medium shot of Cathy teary-eyed, open-mouthed, and swaying with fear that is almost palpable. The moment is made more dramatic when it cuts back to an unperturbed Marko taking out a bottle of champagne that he had "been saving for a special occasion” and cuts 
back to the odd shot of Cathy, this time trying showing her trying to force a tearful smile. This moment of visual excess is followed by one of narrative. Because of the quantity of screen time is devoted to this avenue of inquiry and the tense climax that arises when Marko catches Cathy at his safe, the audience assumes that Cathy's sacrifice will have been worthwhile-that she will now have the proof to clear her husband. However, this anticipated resolution is frustrated when it is revealed that Marko does not have the brooch and was in police custody at the time of the murder —and therefore not the murderer. Cathy, in despair, attempts to express the ineffable—-her realization that her sacrifice has been in vain: "You mean we...All this time, just wasted."

Black Angel is, as many melodramas are, characterized by the return of the repressed. As Peter Brooks argues, "melodrama refuses repression, or rather, repeatedly strives for moments where repression is broken through, to the physical and verbal staging of the essential” (19). The essential in Black Angel is "whodunit?"-who is responsible for Mavis' death? The film—just like the killer, it turns out-attempts to repress the story of the crime but eventually both recall and reveal the truth. Since he met Cathy, Marty has remained sober; however, her rejection of his love sends him on a bender, like the one he went on the night that Mavis was killed. By returning to the same state in which he committed the murder and confronted with the brooch that he and Cathy had been seeking, Marty experiences the return of what he had repressed and an oral and visual montage reveals Marty's actions on the fateful night. As the doctor at the hospital explains, Marty was suffering from "Korsakoff's psychosis," amnesia brought about by his excessive consumption of alcohol. Although he remembers committing the murder and wishes to confess, Marty finds the doctor at the hospital and the police unwilling to believe him—so he has to escape to tell Cathy the truth. Left alone to wait for the arrival of Captain Flood, Marty begins drinking again. In the film's final moment of excess, Marty hallucinates that he sees Mavis 
instead of Cathy: Mavis’ head and body are superimposed over that of Cathy's and eerie music accompanies her disembodied form.

Ultimately the film, in keeping with the melodramatic tradition, is about self-sacrifice. Although Cathy gives herself to Marko, the film suggests that this was an admirable even if futile gesture. However, more importantly, Cathy refuses the temptation to fall for her partner, Marty, who_-as a nice guy_-poses the real threat of replacing Kirk in her affections. Marty professes his love to Cathy: "I knew from the beginning...that you're everything I wanted and everything I'd missed. It has to be you and me, Cathy.” The implication is that his marriage to Mavis was less than ideal and that she was not a good wife, a fact supported by her blackmailing of men like Marko and Kirk. However, Cathy refuses to betray Kirk and tells Marty she can never love another man: “Marty, I can’t. There’s only been one man. There can only be one man...ever.” She is rewarded for her fidelity with Marty's recollection of the truth at the eleventh hour to save Kirk from the gas chamber.

In Woman on the Run, it is not the wife, Eleanor Johnson (Ann Sheridan), who is on the run but her husband Frank (Ross Elliott). He has witnessed a murder and believing that the police cannot protect him from the killer (after all, the victim he saw killed was a witness in police protection), Frank runs. Clear from the start is that Eleanor and Frank's four-year marriage is a disaster. When Inspector Ferris (Robert Keith) asks Frank if he is married, Frank replies, "In a way.” When Ferris asks Eleanor to describe her husband so the police can find him, she retorts, "I couldn’t. I haven’t been able to for a long time.” Ferris is angered by Eleanor's attitude not befitting of a wife, including encouraging her husband to stay on the run.

Ferris: "If I had a husband I wanted to get rid of, I’d do exactly what you did."

Eleanor: "If he wants to run away, that’s his business.”

Ferris: “And your business too, Mrs. Johnson!” 
Indeed, the film suggests that whatever concerns a husband should concern his wife as well: that is her job. As Frank’s doctor tells her, “But naturally, you must know all about his troubles. I’m only his doctor; you're his wife.” But she knows nothing of Frank's life, including that he has a heart condition that has been made more serious because of the stress of their failed marriage.

When Ferris inquires about their relationship, Eleanor replies, "If you want to snoop into the remains of our marriage, that's up to you;" however, the film suggests that it is actually up to her. The mystery that Eleanor as detective must solve is not who shot the witness, but rather who killed the marriage. Frank sends her a riddle in a letter that she must solve: "If you think back, you'll know where to find me.” As newspaperman Danny Leggett (Dennis O’Keefe) says to her, “He’s asking you to admit that your marriage is a failure and that it's your fault. He's saying that he understands you but that you don't understand him.” And he is correct: Eleanor must sift through her memories of the marriage and accept some part of the blame for its going wrong in order to track down her husband and give him his life-saving heart medication. Eleanor neither kept house nor supported her husband's ambitions. Ferris asks why their kitchen contains no food and Eleanor replies, “He’s not particular and I’m lazy, so we eat out.” Ferris asks her why she didn't get a job if she was so concerned about money and she replies, "Why should I? That's his responsibility not mine.” Ferris hits on the truth when he tells Eleanor, “But I don't think you can find him. I don't think he is running away from us; I think he's running away from you.” At the beginning of the film, Eleanor believes that the marriage failed because her husband had let her down by not fulfilling his promise as a successful artist; conversely, through her pursuit of the clues raised in Frank's letter and her resulting investigation of the marriage, Eleanor realizes that she let him down by being too independent. In this film, the repressed that returns is Eleanor's love for her husband and her desire to be a dutiful wife. And for her admission of fault, Eleanor is rewarded with the safe return of her husband. 
The melodramatic moments of the film arise from Eleanor's failure in her attempt to subsume male authority and play detective. Despite the fact that Eleanor proves to be successful in figuring out the clues that lead her to her husband's whereabouts, she ultimately fails to keep her husband safe: by trusting Danny, she leads the killer right to his prey. Danny offers them the money to finance Frank's disappearance in exchange for an exclusive story for his paper. The climax of the film is the rollercoaster ride that Danny takes Eleanor on, initially to spot Frank in the crowd and evade the police, but subsequently to keep her out of the way so that he can kill Frank. On the first ride, Danny and Eleanor sit together and the tension builds as they look for Frank from their vantage point. The scene offers a kind of "phantom ride" with the camera mounted on the front of the car to follow their coasting up and down the tracks. This scene is tense but Eleanor's second ride on the rollercoaster alone is far more melodramatic. As Danny pays to have her ride once more, he reminds her that the killer may try to kill Frank again. The second ride starts then with Eleanor re-hearing both Danny's last comment and Ferris's from earlier that day — that the killer is the only other person who knows about the attempt made on Frank's life. This realization starts an emotional rollercoaster represented through the excess of the cinematography of the literal rollercoaster ride. This time the cacophony of noise, laughter, music, and the roar of the rollercoaster is increased in volume and discord, and is combined with Eleanor's screams for Frank to run away. Instead of a phantom ride offering the view directly ahead of the car, this time the camera looks down through the tracks and over their edge in a series of spiraling, disorienting, and terrifying shots of Frank as a small figure below. Eleanor is yanked from side to side by the motion of the ride, helpless. The most disturbing sound through the entire scene is the mechanical and repetitive laughter of an animatronic figure from an amusement park stall. Eleanor is finally able to get off the ride but a series of shots with dramatic canted angles maintains a sense of her anxiety as she dashes through the amusement park trying 
to find Frank. When she hears a shot fired and sees a body in the water, she—and the audienceassume it is Frank. Luckily, however, the shot fired was Ferris's and the body Danny's. The film suggests that Eleanor's problem at the beginning of the film was her resistance to submit to male authority—that of her husband and the police; however, her eventual acceptance of both leads to a happy conclusion. Eleanor must relinquish her "uxorodespotic" role and, instead, allow her husband to run their household and marriage. ${ }^{15}$

\section{Sacrificial Women}

Phantom Lady, Black Angel, and Woman on the Run all suggest that a marriage cannot be a successful one if the woman vies for control—either inside or outside the home. That is why Black Angel regards Cathy as the superior choice over Mavis for both Kirk and Marty and Phantom Lady sees the replacement of the original Mrs. Henderson (Marcella) with the new one (Carol) as the key to Scott's happiness. While marriage and family are presented as the ideal in classical Hollywood film, in film noir they are presented most often as imprisoning or sterile. As Sylvia Harvey argues, "The two most common types of women in film noir are the exciting, childless whores, or the boring, potentially childbearing sweethearts” (38). However, in the case of Woman on the Run and Black Angel, the threat of death for the husband as an assumed criminal and the working as an independent woman for the wife as a detective-in other words, playing roles outside of those socially sanctioned—facilitates a rejuvenation of the failed marriage and the nurturing wife transformed into an exciting lover figure.

As dutiful wives - in other words, a traditionally female role-these women prove themselves successful; however, as detectives—a traditionally male role-they are exposed ultimately as incompetent. Carol does pursue the bartender doggedly, extract information from the drummer, and locate the phantom lady through her hat and milliner; Cathy does discover that 
both Marty and Marko could have been Mavis' killer; and Eleanor does figure out her husband's riddle and whereabouts. Importantly, many of these discoveries are dependent on specifically female knowledge-i.e. of woman's fashion, the seduction of men, and memories of courtship. On the other hand, in each case, these women befriend the real killers (Jack, Marty, and Danny, respectively) and risk either their own lives or that of their loved ones without realizing what they have done until it is too late. The message of these films is that women can be either the downfall (i.e. the femme fatale) or the savior (i.e. the wife as detective) of men. Wives, who pursue independence outside of marriage whether in terms of sex or a career, present a challenge to male dominance. Ironically, however, through attempting to help their men, these women have to work outside of the home as detectives and sometimes prostitute themselves to other men—and they are never demonized for that, even though the femme fatale always is). Each woman's devotion to the man she loves sees her compensated: in other words, each woman is rewarded with the undivided love of her man—something she did not posses at the beginning of the film. The conclusions of these films are then conservative—if read through the lens of film noir.

If, however, these endings are read through the lens of melodrama, a reading against the grain is made possible. Indeed, the concluding scenes of each film feel contrived, stemming from a desired narrative conclusion of returning women to the home rather than one that logically fits the film that came before it in terms of the actual representation of that narrative. In all three films, the husbands are all but absent and, instead, the relationships that form between their wives and other men (Jack, Marty, and Danny) during the course of the investigation are far more developed, interesting, and exciting. In Phantom Lady, the skipping Dictaphone proposal and addition of a happy-go-lucky score do not convince: Scott was oblivious to Carol's affections for him despite her standing by him through the trial, risking her life to find evidence to exonerate him, and confessing to him that she is in love with her boss. Indeed, the final shot of the film is 
not Carol in Scott's arms but of the Dictaphone horn in hers. Similarly, in Black Angel, the final shot of the film is not the reunion of Kirk and his wife but that of Marty and Cathy on the cover of the sheet music for their hit song “Time Will Tell” and Marty’s comment that they were “a good team while it lasted." In Woman on the Run, the last shot of the film is not of the couple embracing on the midway of the amusement park but of the disturbing animatronic doll as it continues the mechanical cackle that pervaded the rollercoaster ride.

While I have suggested that they share an expressionistic or excessive impulse at the level of representation, film noir and melodrama differ in terms of their ideological motivation. As E. Ann Kaplan suggests,

It is interesting to compare the film noir, with its negative or absent family, with melodrama, a genre in which family and its relations are the focus of ideological representation. While the family melodrama could be seen to deal with the ideological contradictions within patriarchy in terms of sexuality and patriarchal right within the family, the film noir as exemplified by Double Indemnity stresses precisely the ordering of sexuality and patriarchal right, the containment of sexual drives with patriarchy as Symbolic Order. Thus there is a sense in which film noir could be seen to close off the ideological contradictions of patriarchy that the family melodrama opens up. (18)

Thus, Kaplan sees melodrama as functioning in opposition to noir, opening up the possibility of troubling or subverting the film's concession to dominant discourse. However, the focus on a female protagonist and the employ of other conventions of melodrama allow an alternative reading of these films noirs. As Tony Williams, reading Phantom Lady through a psychoanalytic lens, states,

At the climax of the film Carol is confined to the office and the offer of monogamy. However, enough remains of the masochistic model in the film to argue that the aesthetic, 
if not dominant, is there as a fissure, a gap in ideology which permits the partial expression of the female voice. It exists as an alternative operation against patriarchal control of the text. Even if subdued at the climax, it is still there, attempting to strain against narrative bounds. (134)

The apparent endings of the three films may seem to fall in line with the ideological concerns of film noir-i.e. the return of the women to appropriate gender roles-however, the focus on the female characters as investigators (rather than the man as typical with film noir) and the overdetermination of representation (as typical with melodrama) allow for contradictions to resonate past the tacked on endorsement of patriarchal ideology.

In the aftermath of World War II with broken homes and unemployment rampant, the threat, it would seem, was not women replacing men as detectives (as was the fear in the 1930s detective film), but their replacing them as the head of the household. With the return of men from the war, women had to be returned to their proper place so that men could be returned to theirs-at least that was the general social consensus that Hollywood echoed. Just as the maternal melodrama presented "mother-daughter proximity as dangerous to the daughter's future, and to society” (Whitney 11), so too does the film noir starring a female detective suggest that the wife's appropriation of male power in the marriage is dangerous to the husband's future-and to that of society's. Wartime and postwar America needed broken homes mended and gender roles reset to their traditional positions. While the maternal melodrama of the 1930s was "an apologia for total renunciation, total sacrifice, total self-abnegation” (Viviani 96) in a reflection of the impact of the Depression, film noir was similarly a reflection of social attitudes in the 1940s with its recall of women back into the home. Film noir, with its darker, more introspective and critical tone, offered a vehicle for the narratives of men struggling with the new roles demanded of them in postwar America. The ubiquitous female detective of 1930s film could be out-spoken, 
independent, and career-minded with her triumph as both detective and love interest the result of her successful integration of masculinity into femininity. Conversely, the few female detectives of the 1940s had to relinquish their independence (i.e. masculinity) in order to achieve happiness - the only avenue for which was deemed marriage (i.e. femininity). These female detectives, unlike their 1930s counterparts however, seemed happy to submit to marital authority and this is why, in the aftermath of World War II, these women are regarded as meritorious.

\section{Acknowledgments}

The author gratefully acknowledges that financial support for this research was received from a grant partly funded by Wilfrid Laurier University Operating funds and partly by the SSHRC Institutional Grant awarded to WLU. The author would also like to thank Jenny Romero of the Margaret Herrick Library, Heidi Rubenstein of Georgetown University’s Special Collections, and Mark Quigley of the UCLA Film and Television Archive for their assistance.

\section{Notes}

${ }^{1}$ Brown 52-53; Klein 12n3.

${ }^{2}$ For discussion of the contemporary female film detective see Gates, "Manhunting.”

${ }^{3}$ See essays in Kaplan for discussion of the femme fatale. The opposite of the femme fatale-the nurturing woman-has been the subject of some critical discussions; however, she a negligible figure in terms of screen time and narrative control. Instead, the nurturing woman is typically a minor character who is there to offer a contrast or alternative to the femme fatale. See Place for further discussion. While Mildred Pierce (Curtiz 1945) does have a female protagonist (Joan Crawford) who drives the narrative forward, Mildred is the suspected murderer and not the detective and is, ultimately, a sacrificial mother. 
${ }^{4}$ Melodrama is a critical category and a mode of representation that overarches a variety of types of film-including the woman's film, featuring a female protagonist and aimed at a presumably female audience, and the family melodrama, including male protagonists and aimed at an assumed broader audience (Mulvey, “Notes” 76). Having said that, critical attention in film studies has tended to focus on female-centered melodrama because the critics analyzing them have tended to be feminist scholars and theorists.

5 Technically, the term "maritorious" is a manufactured one to offer a parallel for the term “uxorious,” meaning “excessive devotion to one’s wife.” See:

Grandiloquent Dictionary <www.islandnet.com/ egbird/dict/m.htm>

AskOxford <www.askoxford.com/asktheexperts/faq/aboutwords/uxorious?view=uk>

World Wide Words < www.worldwidewords.org/weirdwords/ww-mar1.htm>

6 The Production Code, nicknamed the "Hays Code," was established in 1930 to ensure that "No picture shall be produced which will lower the moral standards of those who see it," as the first general principle of the Code declared. The Code laid out what was or was not considered moral content and scenes that presented the vicarious treatment of sex and violence and the glorification of lawless and amoral behavior were required to be removed if a film was likely to be granted certification by state and national censor boards. Hollywood adopted this system of self-regulatory censorship in order to prevent the institution of federal censorship.

7 For example, although both spinster sleuths Hildegarde Withers in Penguin Pool Murder (Archainbaud 1932) and Sarah Keate in While the Patient Slept (Enright 1935) are proposed to by the police detectives officially in charge of the investigation, both remained unmarried for all six of their respective films. Similarly, although Torchy Blane and her police detective boyfriend continually aim to get married, Torchy returns unattached for all nine films. 
${ }^{8}$ Other interesting films noirs that offer female detectives are The Seventh Victim (Robson 1943) and Shadow of a Doubt (Hitchcock 1943). Both detectives are teenagers and therefore the plots of these films differ from the ones with which this paper is concerned. In The Seventh Victim, Mary Gibson (Kim Hunter) investigates the satanic cult with which her sister is involved. In Shadow of a Doubt, 'Charlie’ Newton (Teresa Wright) investigates her suspicion that her uncle is a murderer and he subsequently attempts to murder her.

${ }^{9}$ For a complete discussion of the history of film noir criticism, see Neale (Genre Ch. 4).

${ }^{10}$ See Bratton et al., Doane, and Gledhill.

${ }^{11}$ See Doane, Gledhill, and Nowell-Smith.

${ }^{12}$ See Gates. “The Man’s Film.”

${ }^{13}$ See Krutnik.

${ }^{14}$ As Diane Waldman explains, "The plots of films like Rebecca, Suspicion, Gaslight, and their lesser-known counterparts like Undercurrent and Sleep My Love fall under the rubric of the Gothic designation: a young inexperienced woman meets a handsome older man to whom she is alternately attracted and repelled. After a whirlwind courtship (72 hours in Lang's Secret Beyond the Door, two weeks is more typical), she marries him. After returning to the ancestral mansion of one of the pair, the heroine experiences a series of bizarre and uncanny incidents, open to ambiguous interpretation, revolving around the question of whether or not the Gothic male really loves her. She begins to suspect that he may be a murderer” (29-30).

15 Uxorodespotic means "tyrannical rule by one’s wife." See Babylon: <www.babylon.com/definition/uxorodespotic/English> 


\section{REFERENCES}

Bratton, Jacky, Jim Cook, and Christine Gledhill, Eds. Melodrama: Stage, Picture, Screen. London: BFI Publishing, 1994.

Brooks, Peter. “Melodrama, Body, Revolution.” Melodrama: Stage, Picture, Screen. Eds. Jacky Bratton, Jim Cook, and Christine Gledhill. London: BFI Publishing, 1994. 11-24.

Brown, Jeffrey A. "Gender and the Action Heroine: Hardbodies and the Point of No Return." Cinema Journal 35:3 (1996): 52-71.

Cook, Pam. "Duplicity in Mildred Pierce.” Women in Film Noir. Ed. E. Ann Kaplan. New Ed. London: BFI Publishing, 2001. 69-80.

Doane, Mary Ann. The Desire to Desire: The Woman's Film of the 1940s. Bloomington: Indiana University Press, 1987.

Gale, Steven H. “The Maltese Falcon: Melodrama or Film Noir?” Literature/Film Quarterly 24.2 (1996) 145-48.

Gates, Philippa. "Manhunting: The Female Detective in the Contemporary Serial Killer Film.” Post Script: Essays in Film and the Humanities 24:1 (2004): 42-61.

. “The Man’s Film: Woo and the Pleasure of Male Melodrama.” The Journal of Popular Culture 35:1 (2001): 59-79.

Gledhill, Christine. "The Melodramatic Field: An Investigation.” Home is Where the Heart is: Studies in Melodrama and the Woman's Film. Ed. Christine Gledhill. London: BFI Publishing, 1987. 5-39.

Hanson, Philip. “The Feminine Image in Films of the Great Depression.” The Cambridge Quarterly 32:2 (2003): 113-41.

Harvey, Sylvia. “Woman’s Place: The Absent Family of Film Noir.” Women in Film Noir. Ed. E. Ann Kaplan. New Ed. London: BFI Publishing, 2001. 35-46. 
Internet Movie Database (IMDb) <http://www.imdb.com>

Kaplan, E. Ann. “Introduction to 1978 Edition.” Women in Film Noir. Ed. E. Ann Kaplan. New Ed. London: BFI Publishing, 2001. 15-19.

Klein, Kathleen Gregory. The Woman Detective: Gender and Genre. $2^{\text {nd }}$ ed. Urbana: University of Illinois Press, 1995.

Krutnik, Frank. In a Lonely Street: Film Noir, Genre, Masculinity. London, Routledge, 1991.

Kungl, Carla T. Creating the Fictional Female Detective: The Sleuth Heroines of British Women Writers, 1890-1940. Jefferson, NC: McFarland \& Company, 2006.

Modleski, Tania. Loving with a Vengeance: Mass-Produced Fantasies for Women. Hamden, CT: Archon Books, 1982.

Mulvey, Laura. “'It will be a Magnificent Obsession:' The Melodrama's Role in the Development of Contemporary Film Theory.” Melodrama: Stage, Picture, Screen. Eds. Jacky Bratton, Jim Cook, and Christine Gledhill. London: BFI Publishing, 1994. 121-33. . "Notes on Sirk and Melodrama." Home is Where the Heart is: Studies in Melodrama and the Woman’s Film. Ed. Christine Gledhill. London: BFI Publishing, 1987. 75-79.

Naremore, James. “American Film Noir: The History of an Idea.” Film Quarterly 49:2 (1995/1996): 12-28.

Neale, Steve. Genre and Hollywood. London: Routledge, 2000.

. "Melo Talk: On the Meaning and Use of the Term 'Melodrama' in the American Trade Press.” Velvet Light Trap 32 (1993): 66-89.

Nickerson, Catherine Ross. The Web of Iniquity: Early Detective Fictions by American Women. Durham, NC: Duke University Press, 1998.

Nowell-Smith, Geoffrey. "Minnelli and Melodrama." Home is Where the Heart is: Studies in Melodrama and the Woman’s Film. Ed. Christine Gledhill. London: BFI Publishing, 1987. 
70-74.

Phelps, Donald. “Cinema Gris: Woolrich/Neill’s Black Angel.” Film Comment (2000): 64-69.

Place, Janey. "Women in Film Noir.” Women in Film Noir. Ed. E. Ann Kaplan. New Ed. London: BFI Publishing, 2001. 47-68.

Singer, Ben. "Female Power in the Serial-Queen Melodrama: The Etiology of an Anomaly." Camera Obscura 22 (1990): 91-129.

Viviani, Christian. "Who is Without Sin? The Maternal Melodrama in American Film, 1930-39." Home is Where the Heart is: Studies in Melodrama and the Woman's Film. Ed. Christine Gledhill. London: BFI Publishing, 1987. 83-99.

Waldman, Diane. “‘At Last I Can Tell It to Someone!’ Feminine Point of View and Subjectivity in the Gothic Romance Film of the 1940s.” Cinema Journal 23.2 (1984): 29-40.

Williams, Tony. “Phantom Lady, Cornell Woolrich, and the Masochistic Aesthetic.” Film Noir Reader. Eds. Alain Silver and James Ursini. $7^{\text {th }}$ Limelight Ed. New York: Limelight Editions, 2003. 129-43.

Whitney, Allison. "Race, Class, and the Pressure to Pass in American Maternal Melodrama: The Case of Stella Dallas.” Journal of Film and Video 59.1 (2007): 3-18.

\section{SELECTED FILMOGRAPHY}

Black Angel (1946) Dir. Roy William Neill. Prod. Universal Pictures. Perf. Dan Duyea, June Vincent, and Peter Lorre.

Phantom Lady (1944) Dir. Robert Siodmak. Prod. Universal Pictures. Perf. Franchot Tone, Ella Raines, and Alan Curtis.

Woman on the Run (1950) Dir. Norman Foster. Prod. Fidelity Pictures Corp. Perf. Ann Sheridan, Dennis O’Keefe, and Robert Keith. 